\title{
Dawid LATAŁA
}

\section{ANALIZA PROCESU OBSKUGI MAGAZYNU Z WYKORZYSTANIEM MODUKU WM SAP R/3}

Na przykładzie oprogramowania SAP w module magazynowym WM $w$ artykule omówiona została szczegółowa analiza procesu obstugi magazynu w wybranym przedsiębiorstwie produkcyjnym. Praktyczny opis czynności magazynowych przybliży znaczenie użytkowania systemu zarządzania WM oraz pozwoli na ocenę procesu magazynowania.

\section{WSTĘP}

Magazyny w zależności od wielkości i rodzaju produkcji można podzielić wg różnych kategorii opisujących ich rodzaj, lokalizację, warunki przechowywania oraz zastosowane urządzenia wspomagające pracę. Każdy magazyn, aby mógł sprawnie funkcjonować musi być odpowiednio zarządzany. Efektywne zarządzanie magazynem w przedsiębiorstwie zależy przede wszystkim od dobrze zorganizowanego systemu przepływu informacji. Jednym z systemów informatycznych, wspomagających zarządzanie magazynem jest system klasy ERP - SAP. Moduł, który odpowiada za sprawną organizację procesów magazynowych to Warehouse Management (skr.WM). Dzięki tym narzędziom proces przyjmowania, składowania, przechowywania i wydawania towarów stał się dużo prostszy w porównaniu od procesów w starej strukturze, gdzie poszczególne zadania wymagały dużego nakładu środków i pracy [4].

\section{PROCES PRZYJMOWANIA TOWARU NA MAGAZYNIE W MODULE WM}

Przed rozpoczęciem korzystania z oprogramowania SAP Warehouse Management (WM), należy w pierwszej kolejności zdefiniować strukturę (układ fizyczny) magazynu. W trakcie implementacji systemu definiowane sa podstawowe parametry przedsiębiorstwa, za pomoca transakcji SPRO. Struktura magazynu ma układ hierarchiczny i składa się z następujących elementów:

- zakład,

- magazyn,

- strefa,

- regał,

- półka,

- gniazdo.

Strukturę magazynową przedsiębiorstwa produkcyjnego przedstawia rys. 1.

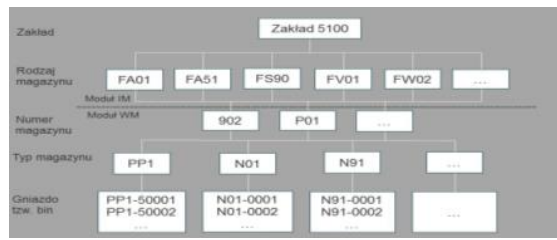

Rys. 1. Struktura magazynowa przedsiębiorstwa produkcyjnego Źródło: opracowanie własne na podstawie przedsiębiorstwa produkcyjnego
W przedsiębiorstwie istnieje jeden zakład, jednak możliwe jest tworzenie większej liczby zakładów w jednej organizacji. Przykładem może być przedsiębiorstwo posiadajace filie/oddziały, gdzie magazynowanie towarów następuje w jednej firmie, ale dla odrębnych zakładów.

Magazyny w zakładzie to miejsca służące do przechowywania zapasów. llość tworzonych magazynów jest dowolna i uzależniona od rodzaju prowadzonej działalności oraz grup asortymentowych towarów. Rys. 1 przedstawia magazyny, w którym składowane sa: nowe partie towaru (FA01); nowe partie towaru z przypisanymi numerami opakowania (towar identyfikowany po numerze opakowania)(FA51)); rurki (FS90); wyroby gotowe - magazyn wysyłkowy (FV01) oraz materiały chemiczne (FW02). Magazyny te moga stanowić odrębne pomieszczenia lub znajdować się w jednej lokalizacji podzielonej na obszary. Każdemu z nich przypisany jest indywidualny numer w celu odróżnienia i łatwiejszej identyfikacji.

Dalszy podział to rozróżnienie magazynów, w których realizowane są konkretne funkcje magazynowe: strefa przyjęć oraz kompletacji, wydań. W strefie przyjęć znajdują się magazyny logiczne (magazyny przejściowe). Służą do tymczasowej lokalizacji towaru po przyjęciu dostawy, a przed wydaniem do składowania (902) oraz na czas dokonywania kontroli jakościowej towaru (P01).

Typy magazynów oznaczone numerami identyfikacyjnymi (N01), przeznaczone są dla określonej partii towaru.

Regały podzielone na półki, tj. zestaw gniazd umieszczonych na tym samym poziomie. Gniazda, tzw. biny to podstawowy element przestrzeni magazynowej, w której składowane są towary w jednostce ładunkowej, jaką jest paleta (PP1-50001). W innych przedsiębiorstwach rodzaj przyjętego gniazda może być indywidualny, np. karton, pudełko. Rozmiar każdego z gniazd dopasowany jest do wymiarów wybranej jednostki ładunkowej.

Proces przyjęcia towaru na magazyn obejmuje czynności zwiazane z fizycznym przyjęciem dostawy, a następnie wprowadzenie danych dostawy do systemu SAP w module WM. Przyjęcie towaru odbywa się według zasady FIFO - pierwsze weszło, pierwsze podlega przyjęciu. Stosując się do tej zasady zachowuje się porządek i unika chaosu. Wyjątkiem są towary, które zostały dostarczone do magazynu z opóźnieniem, a które wymagane są pilnie w procesie produkcyjnym - w przypadku zagrożenia zatrzymania linii produkcyjnej.

Podstawowe działania, jakie mają miejsce w obszarze logistyki wejściowej przedstawia rys. 2. 

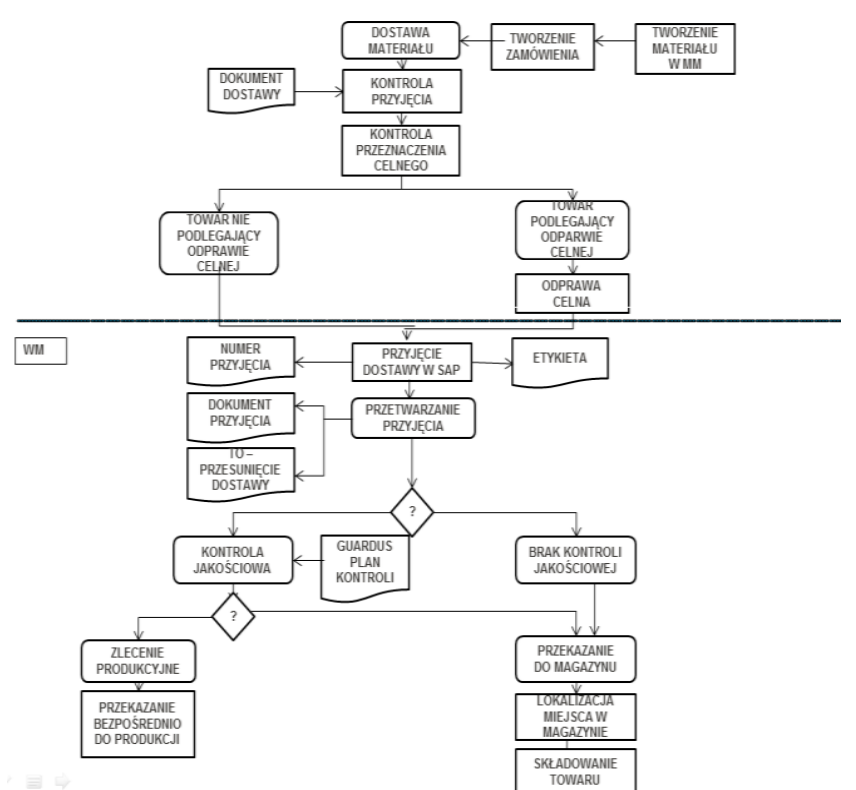

Rys. 2. Schemat procesu przyjęcia towaru

Źródło: opracowanie własne na podstawie przedsiębiorstwa produkcyjnego

Ważnym elementem przed przyjęciem towaru jest utworzenie pozycji materiałowych w SAP, przez nadanie im indeksu materiałowego. Odpowiednio zdefiniowane parametry materiału służa do określenia jego miejsca w magazynie. Lokalizacja materiału zostaje automatycznie przypisywana przez WM podczas procesu przyjęcia towaru. Dane materiałowe wykorzystywane są również podczas procesów sprzedaży, procesów związanych z zarządzaniem magazynem i księgowaniem.

Rys. 3 przedstawia rodzaj transakcji służącej do tworzenia materiału oraz niezbędne dane materiałowe wykorzystywane w logistyce magazynowej.

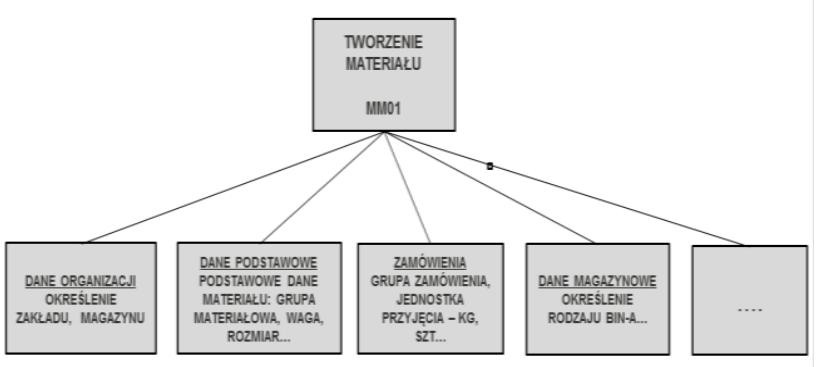

Rys. 3. Tworzenie materiału

Żródło: opracowanie własne na podstawie SAP

Uzupełnianie lub modyfikowanie wprowadzonych danych możliwe jest przy użyciu transakcji MM02. W celu wyświetlenia danych materiałowych posługujemy się transakcją MM03.

Po zdefiniowaniu i utworzeniu danych materiałowych istotne w procesie przyjęcia jest zapotrzebowanie asortymentowe. Tworzenie zapotrzebowania/zamówienia jest etapem, który zapoczątkowuje wiele późniejszych operacji związanych z obsługa magazynu. Złożenie zamówienia powoduje powstanie w systemie zapisu obejmujacego wszystkie dane dotyczace spodziewanej dostawy. Zapis ten informuje do kogo skierowane zostało zamówienie, jakie jest zapotrzebowanie na asortyment. Z punktu widzenia informatycznego etap ten jest niezbędny w zarządzaniu całym łańcuchem dostaw, ponieważ rozpoczyna czynności związane z nadzorowaniem ruchu materiału. W module WM funkcja tworzenia zamówienia występuje po to, aby mieć odniesienie do dalszych działań. Jeżeli jej nie będzie, niemożliwe staje się rozpoczęcie procesu magazynowania.
Każdy pozycja materiałowa, który trafia do magazynu musi mieć odniesienie do faktycznej dostawy wynikającej z zamówienia.

Generowanie zamówień w systemie klasy ERP oparte jest o reguły zamawiania metodą MRP. Zlecenie przyjęcia na określony asortyment, wynikające z przeprowadzonych procedur zamawiania w ERP, przekazywane jest do WM. Kolejno następuje składowanie towaru. Magazyn nie generuje zamówień. Zamówieniami zewnętrznymi zajmuje się dział zaopatrzenia materiałowego, który ma wpływ na to co jest składowane.

Proces tworzenia zamówienia rozpoczyna się od zgłoszenia zapotrzebowania. Zgłoszenie zapotrzebowania jest dokumentem, który tworzony jest automatycznie w trakcie planowania potrzeb materiałowych lub można go wygenerować samodzielnie. Dokument ten wykorzystuje dane znajdujace się w systemie, które w wielu przypadkach sa ze sobą połaczone, jak np. źródła dostawy ustalane są przez powiazzanie $z$ indeksem materiałowym - dostawca.

Samodzielne tworzenie zapotrzebowania następuje z wykorzystaniem transakcji ME51N. Konieczne jest tutaj określenie przedmiotu i ilości zapotrzebowania przy pomocy indeksu materiałowego. Następnie ustala się źródło dostaw. Wybór dostawcy dokuje się z listy dostawców. Dane o dostawcach pobierane są z zapisów informacyjnych zaopatrzenia. Zapis informacyjny jest kombinacja danych materiału i danych dostawcy. Po dokonaniu wyboru dostawcy zapisujemy wprowadzone dane, a system generuje numer zgłoszenia zapotrzebowania.

Wygenerowane zgłoszenie zapotrzebowania jest podstawą do utworzenia zamówienia zakupu. Zamówienie może być utworzone samodzielnie przy pomocy transakcji ME21N lub automatycznie ze zgłoszeń zapotrzebowania wykorzystując transakcję ME58 lub ME59N.

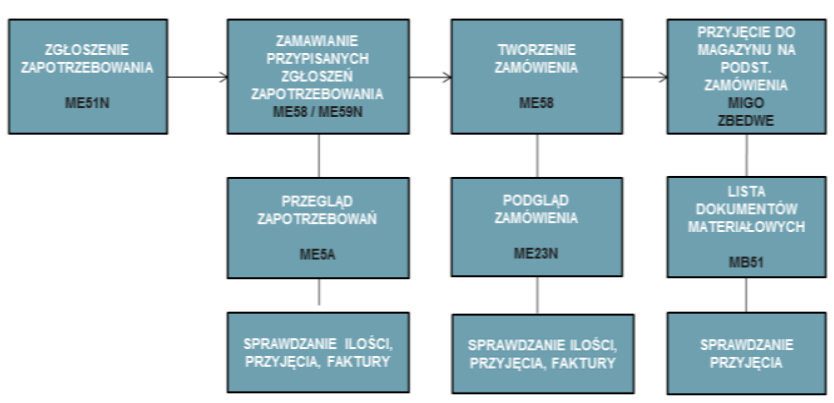

Rys. 4. Proces tworzenia zamówienia Żródło: opracowanie własne na podstawie SAP

Rezultatem poprawnie utworzonego zamówienia zakupu jest nadanie przez system numeru o kombinacji 10-cio cyfrowej, np. 4500441452.

Zamówienie zakupu jest podstawą przyjęcia towaru do magazynu. Na każdym dokumencie dostawy powinien widnieć numer zamówienia, co pozwoli na szybka identyfikację w SAP. W przypadku braku numeru zamówienia możliwe jest jego odszukanie poprzez numer materiałowy, przy użyciu transakcji ME2M. Jeśli jednak nie znamy numeru zamówienia, ani numeru materiału szukamy go po dostawcy - transakcja ME2L.

Rejestracja przyjęcia do magazynu obsługiwana jest przez transakcję MIGO, przy której konieczne jest podanie numeru zamówienia. 


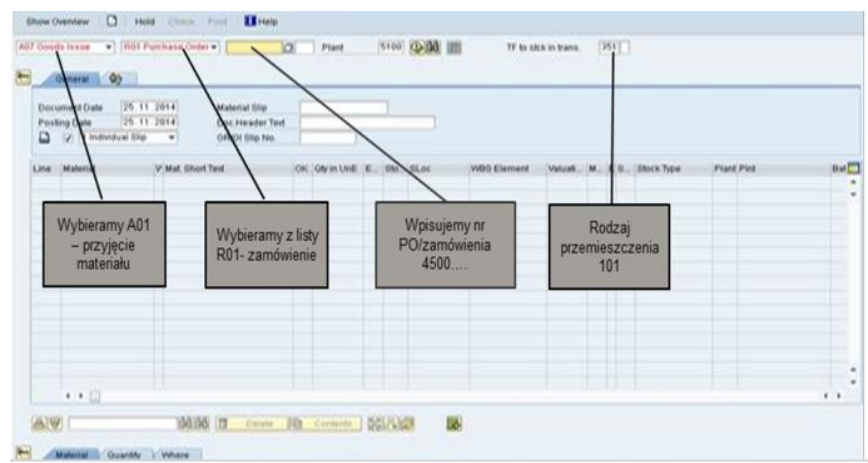

Rys. 5. Transakcja MIGO

Źródło: opracowanie własne na podstawie SAP

Po uruchomieniu transakcji MIGO (rys. 5) ustawiany jest tryb pracy jako przyjęcie materiałów A01 (możliwe inne opcje, np. do składania reklamacji). Następnie powiązuje się_tą operację z zamówieniem R01 oraz rodzajem przemieszczenia materiału 101 (przyjęcie od dostawcy). Po wybraniu opcji, odpowiadających przyjęciu dostawy, wprowadza się numer zamówienia przypisany do otrzymanej dostawy. Następnie należy zatwierdzić wybrane dane. System kopiuje dostępne pozycje z wcześniej utworzonego zamówienia do dokumentu przyjęcia. Mając podglad pozycji asortymentowych weryfikujemy ich poprawność z dostawa. W zmówieniu może wystapić jedna lub więcej pozycji. Dostawa towaru niekoniecznie musi być realizowana jednorazowo w całości. Bywa, że towar dostarczany jest w partiach, w odstępach czasowych. W tej sytuacji zaznaczyć należy faktycznie otrzymaną pozycję asortymentowa, potwierdzić ilość materiału (może być inna od zamówionej) i wprowadzić numer dokumentu dostawy, np. nr faktury, nr listu przewozowego lub inny dowód dostawy. Po wprowadzeniu danych dla poszczególnych pozycji należy zapisać wprowadzone dane. Wówczas w dolnej części ekranu pojawi się zapis z numerem utworzonego dokumentu materiałowego: „Dokument materiałowy 5014303... zaksięgowany”. System aktualizuje zapas przyjmowanego materiału we wskazanej lokalizacji.

Po zaksięgowaniu dokumentu materiałowego system automatycznie generuje dokument potwierdzający przyjęcie towaru, drukując: „Przyjęcie towaru”, „Dostawę wewnętrzna”, „Miejsce magazynowe" oraz etykietę przyjęcia towaru.

Podstawowe dane znajdujące się na dokumencie „Przyjęcie towaru”(ang. Goods Receipt Slip), ważne dla logistyki magazynowej to:

- numer dokumentu,

- data wygenerowanego dokumentu wraz z godzina,

- numer zamówienia,

- rodzaj przemieszczenia - 101,

- nazwa i ilość materiału (w przypadku kilku pozycji widoczna jest pierwsza z nich),

- numer zakładu/numer magazynu,

- nazwa dostawcy i numer dokumentu dostawy,

- dane osoby przyjmujacej towar.

- informacja o kontroli jakościowej TAK lub NIE.

„Dostawa wewnętrzna” (ang. Inbound Delivery) zawiera identyczne dane z "Przyjęciem to-waru”, z wyjątkiem podziału asortymentu na poszczególne pozycje (w przypadku przyjęcia więcej niż jednej pozycji).

„Miejsce magazynowe” (ang. Stock placement) jest dokumentem, który określa miejsce magazynowe przyjętego towaru. Dzięki wcześniej określonym parametrom materiału (zakład, magazyn miejsce magazynowe, itd.) system automatycznie przydziela miejsca składowania towaru podczas przyjęcia. Podstawowe dane dokumentu to:
- numer przesunięcia materiału, tzw. TO - transfer order,

numer materiału,

data przyjęcia i numer "Przyjęcia towaru”,

rodzaj przesunięcia, np. $101-911$,

miejsca przesunięcia, np. 902 - PP1,

miejsce magazynowe.

TO - przesunięcie materiałowe - oznacza ruch magazynowy materiału z jednej lokalizacji do innej. Każde przesunięcie oznaczone jest indywidualnym numerem identyfikacyjnym.

Rodzaj przesunięcia - podczas przyjęcia od dostawcy typ przesunięcia zawsze oznaczony jest symbolem 101.

Miejsce przesunięcia - automatyczne systemowe przesunięcie z magazynu przyjęcia do wyznaczonego magazynu składowania (identyfikacja po parametrach materiału)

Miejsce magazynowe - docelowe gniazdo materiału.

W przedsiębiorstwie produkcyjnym występują towary, na których konieczne jest przeprowadzenie kontroli jakościowej, przed wyznaczeniem docelowego miejsca składowania. Po przyjęciu towaru system kieruje automatycznie towar z magazynu przyjęcia (902) do magazynu kontroli jakościowej (PP1), wyznaczając miejsce magazynowe (PP1-50032). Po dokonaniu kontroli jakościowej i zatwierdzeniu wyniku w systemie jakości „Guardus” (system zarzadzania jakością - każdy otrzymany od dostawców towar jest kontrolowany zgodnie z planem przechowywanym w GUARDUS, a wyniki ewidencjonowane w systemie) towar zostaje przesunięty (rodzaj przesunięcia 911) do docelowego magazynu przy użyciu transakcji LT10. System generuje kolejny dokument "Miejsce magazynowe” z nowymi parametrami przesunięcia, wyznaczając miejsce docelowe towaru.

Etykieta przyjęcia towaru oznacza faktyczne przyjęcie w systemie. Naklejana na jednostki ładunkowe (palety) informuje o możliwości składowania towaru. Jej podstawowe dane to:

- data wystawienia,

- osoba tworząca przyjęcie,

- przeznaczenie ( magazyn, dział),

- nr materiału,

- ilość,

- nr dokumentu przyjęcia.

\section{SPOSOBY PRZEMIESZCZANIA TOWARU W MODULE WM SAP R/3}

W przedsiębiorstwie produkcyjnym istnieja procesy przyjęcia materiału do innych magazynów, polegające na potwierdzeniu przesunięcia materiałów - TO pomiędzy logistyką wejściową a magazynem docelowym, z poziomu WM. Przesunięcie magazynowe zawiera wszystkie informacje konieczne do wdrożenia ruchu magazynowego i jednocześnie jest instrukcja z księgowego punktu widzenia, dotyczącą transportu określonej ilości materiału z jednego miejsca magazynowego/gniazda do kolejnego. Potwierdzenie TO polega na potwierdzeniu ilości materiału oraz ruchu magazynowego z jednej lokalizacji do następnej według informacji zawartej w TO. Efektem tego jest zmiana statusu TO na kompletny.

Informacje o tym, gdzie dany materiał powinien zostać przemieszczony można znaleźć $w$ danych podstawowych materiału, w zakładce WM - zarządzanie magazynem. Wykorzystujemy w tym celu transakcję MM03. 


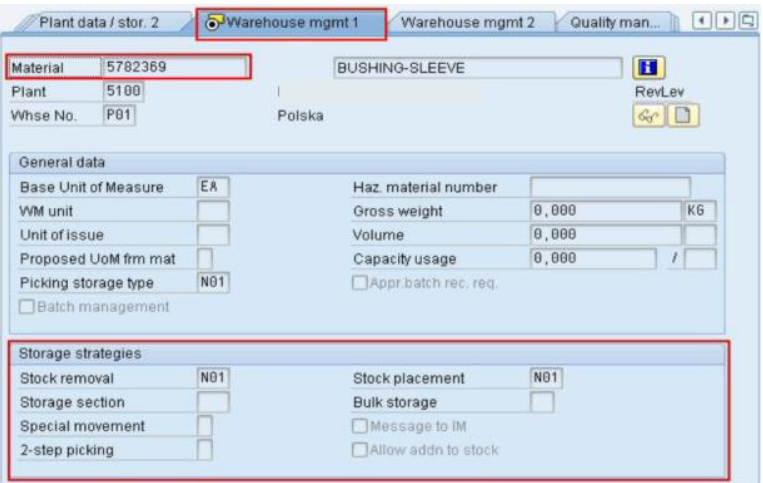

Rys. 6. Transakcja MM03

Żródło: opracowanie własne na podstawie SAP

Na rys. 6 docelowym magazynem materiału jest magazyn N01.

Proces przemieszczania materiału do docelowego magazynu, w tym przypadku magazynu procesów specjalnych N01, odbywa się na podstawie wcześniej wprowadzonych danych materiałowych. W momencie przyjęcia materiałów na logistykę wejściową system generuje polecenie TO do magazynu N01. Oznacza to, że dany materiał został zarezerwowany dla magazynu N01, jednak do czasu zatwierdzenia TO będzie widniał na stanie magazynu transferowego 902 lub w sytuacji potrzeby dokonania kontroli jakościowej w magazynie kontroli jakości P01.

Schemat procesu przepływu materiału i przesunięcia TO obrazuje poniższy schemat. Czynności wykonywane w trakcie przemieszczenia można podzielić na trzy grupy:

- fizyczny przepływ materiału,

- przebieg procesu w systemie SAP,

- generowanie dokumentów w SAP.

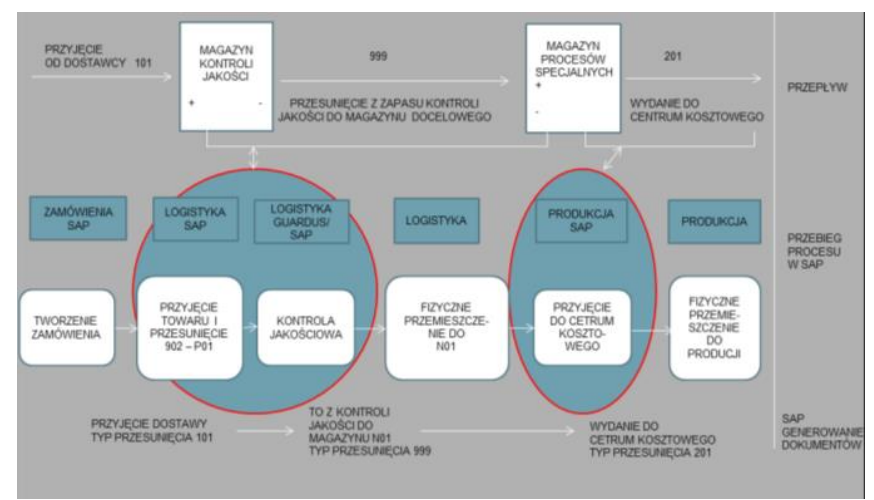

Rys. 7. Schemat przesunięcia TO

Żródło: Opracowanie własne na podstawie przedsiębiorstwa produkcyjnego

Transakcje używane podczas przesunięć TO:

LT22 - przesunięcie na podstawie danych o magazynie,

LT23 - przesunięcie z wykorzystaniem listy TO,

LT24 - przesunięcie na podstawie numeru materiału,

LT21 - wyświetlanie pojedynczego TO.

Transakcja LT22 umożliwia wyświetlanie wszystkich otwartych i niepotwierdzonych TO dla określonego magazynu, w tym przypadku dla magazynu N01.

W głównym oknie dialogowym LT22 należy wpisać zakres wyszukiwania dla rodzaju magazynu P01 - N01. Z danych materiałowych lub dokumentu TO wygenerowanego po przyjęciu towaru wiadomo, że materiał znajduje się w lokalizacji P01 i jego miejscem docelowym jest magazyn N01.

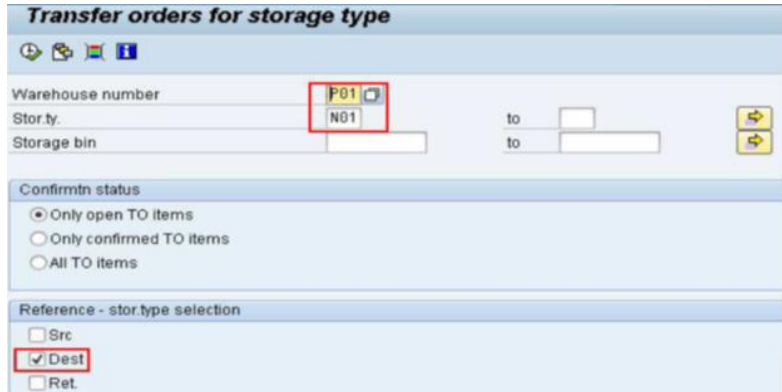

Rys. 8. Zdjęcie 9. Transakcja LT22

Żródło: opracowanie własne na podstawie SAP

Wybranie opcji miejsca przeznaczenia pozwoli na wyświetlenie wszystkich TO do magazynu N01.

Listę wszystkich TO, które nie zostały do tej pory potwierdzone przedstawia rys. 9.

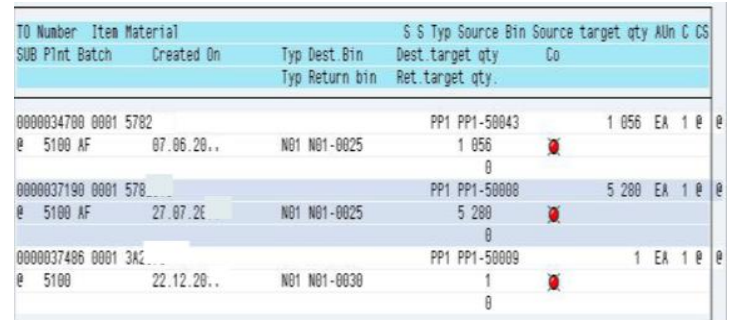

Rys. 9. Lista TO - transakcja LT22

Źródło: opracowanie własne na podstawie SAP

Pozycje oznaczone kolorem czerwonym informują użytkownika o tym, że materiał oczekuje na przemieszczenie - wykonanie ruchu magazynowego TO.

W celu przemieszczenia materiału wybiera się interesująca pozycję i kolejno zatwierdza „wózkiem”.

\begin{tabular}{|c|c|c|}
\hline \multicolumn{3}{|c|}{ Transfer Orders: List by Storage Type } \\
\hline \multicolumn{2}{|c|}{ 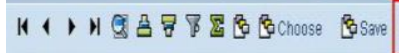 } & 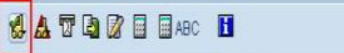 \\
\hline Harehouse No. Pe1 Polska & & Confirmation in Background (Ctrl + Shift +5 ) \\
\hline \multirow{2}{*}{$\begin{array}{l}\text { To Nunber Iten Naterial } \\
\text { SUB PInt Batch Created on }\end{array}$} & & S S Typ Source Bin Source target aty RUn C CS \\
\hline & $\begin{array}{l}\text { Typ Dest Bin } \\
\text { Typ Return bin }\end{array}$ & $\begin{array}{l}\text { Dest target qty co } \\
\text { Ret target qty. }\end{array}$ \\
\hline $0000034790800057782 \ldots$ & & 1856 ER 18 \\
\hline e $\quad 5100 \mathrm{AF}$ & No1 N01-8025 & 1856 \\
\hline
\end{tabular}

Rys. 10. Potwierdzenie przesunięcia materiału - LT22

Źródło: opracowanie własne na podstawie SAP

System przetwarzając wprowadzone dane dokona przemieszczenia z magazynu P01 - N01, wybierajac automatycznie miejsce nowego gniazda. Materiał znajdujący się do tej pory w lokalizacji PP1-50043 zmieni miejsce na pozycję nadana mu przez system na N01-0025.

TO ze statusem w kolorze zielonym oznacza dokonanie przemieszczenia.

\begin{tabular}{|c|c|c|c|}
\hline \multicolumn{2}{|l|}{ To Nubber Iten Material } & \multicolumn{2}{|c|}{ \$S Typ Source Bin Source target aty \&Un C CS } \\
\hline SUB PInt Batch Created on & $\begin{array}{l}\text { Typ Dest. Bin } \\
\text { Typ Return bin }\end{array}$ & $\begin{array}{l}\text { Dest. target aty } \\
\text { Ret. target aty. }\end{array}$ & co \\
\hline $080003470080015782:$ & & PP1 PP1.50843 & 1056 Es $1=$ \\
\hline e $5100 \mathrm{AF} \quad$ 87.86.28\%: & Ne1 Ne1-8025 & $\begin{array}{r}1856 \\
\theta\end{array}$ & 0 \\
\hline $0000037190080157822^{\cdots}$ & & PP1 PP1.50088 & 5280 ER 18 \\
\hline e. $5100 \mathrm{AF}$ & N01 N01-8025 & $\begin{array}{r}5280 \\
8\end{array}$ & - \\
\hline $0000037486008113 k 23^{--}$ & & PP1 PP1.50009 & 1 ER $1=$ \\
\hline e $5100 \quad 22.12 .20 \mathrm{c}$ & N01 Ne1-8038 & $\begin{array}{l}1 \\
\theta\end{array}$ & 0 \\
\hline
\end{tabular}

Rys. 11. Widok po potwierdzeniu przesunięcia - LT22 Źródło: opracowanie własne na podstawie SAP 
Przemieszczenia między magazynami można również dokonać w odniesieniu do danego materiału. W przypadku, gdy nieznane jest oznaczenie magazynu docelowego i nie jest możliwe wyszukanie go po numerze w LT22 korzystamy z transakcji LT24. Umożliwia ona przemieszczenie według numeru materiału. Okno dialogowe wyglada pokazuje rys. 12 .

\begin{tabular}{|c|c|c|}
\hline \multicolumn{3}{|c|}{ Transfer Orders for Material } \\
\hline \multicolumn{3}{|l|}{ (4) 绝)=(固 } \\
\hline Warehouse number & P01 & \\
\hline Material & 5782310 & 0 \\
\hline
\end{tabular}

Rys. 12. Transakcja LT24

Żródło: opracowanie własne na podstawie SAP

Kolejne kroki zatwierdzania TO w LT24 dokonuje się analogicznie jak w transakcji LT22, z wyjątkiem wyświetlania listy niezatwierdzonych TO. W tym przypadku zamiast wyświetlania pozycji dla wybranego magazynu pojawia się pozycja dla wprowadzonego numeru materiału. Zazwyczaj jest to jedna pozycja, z uwagi na bieżące wykonywanie procesów przemieszczenia. Wyjątkiem może być sytuacja, kiedy system wyświetli więcej niż jedna pozycję, np. w przypadku skumulowania w jednym czasie zamówień/dostaw lub otrzymany wcześniej materiał został wstrzymany przez kontrolę jakości, a następnie zwolniony z opóźnieniem.

W celu sprawdzenia wszystkich oczekujacych i zatwierdzonych TO skorzystać należy z transakcji LT23, która wyświetla listę materiałów z odpowiednimi oznaczeniami: czerwony status - niezatwierdzone, zielony zatwierdzony. W oknie dialogowym wybiera się numer dowolnego magazynu, z którego ma nastapić lub już nastapiło przemieszczenie. Inna opcja jest wpisanie przemieszczenia z zakresem numerów TO lub zakresu dat TO. Możliwe jest również ograniczenie zakresu wyświetlanych TO do :

- otwartych,

- potwierdzonych,

- wszystkich.

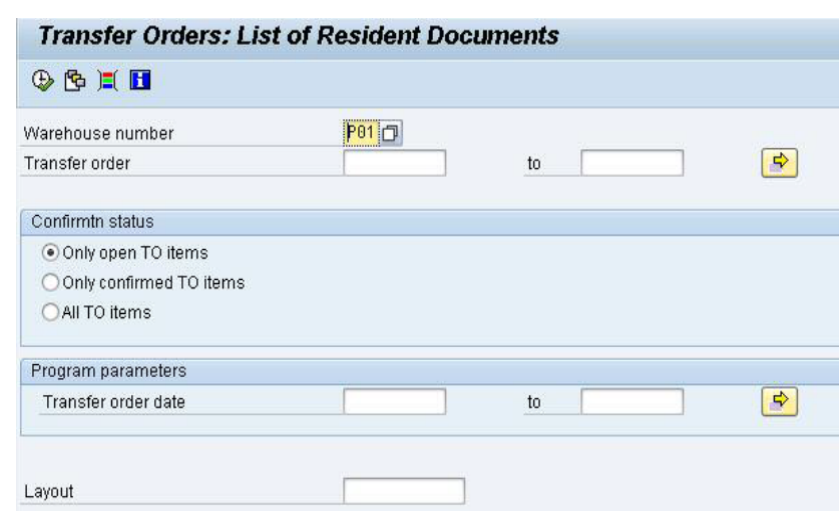

Rys. 13. Transakcja LT23

Źródło: opracowanie własne na podstawie SAP

Po dokonaniu przemieszczenia, wykorzystujac dowolna z przedstawionych transakcji, istnieje możliwość wyświetlania danych o przesunięciu. Służy do tego transakcja LT21.

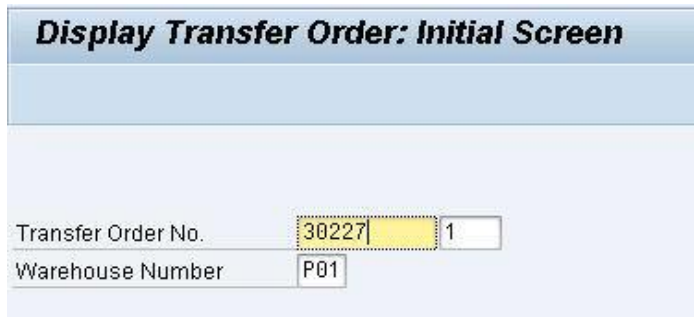

Rys. 14. Transakcja $L T 21$

Źródło: opracowanie własne na podstawie SAP

Po wpisaniu numeru interesującego nas TO można podglądnąc szczegóły poprzez zatwierdzenie -ENTER.

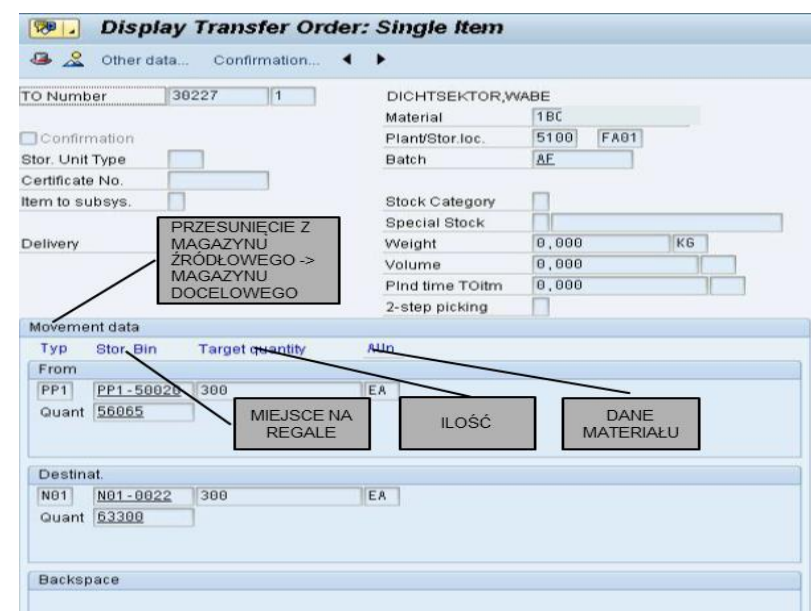

Rys. 14. Podgląd pojedynczego TO - LT21

Źródło: opracowanie własne na podstawie SAP

Najważniejsze informacje dostępne w tym poleceniu to:

- dane przesunięcia $z$ ang. Movement data,

- miejsce docelowe, gniazdo z ang. Storage Bin,

- ilość z ang. Target quantity,

- dane materiału.

LT21 daje również możliwość potwierdzenia pojedynczego TO. Odbywa się to poprzez wybór ścieżki: TO -> potwierdzenie -> TO -> ENTER.

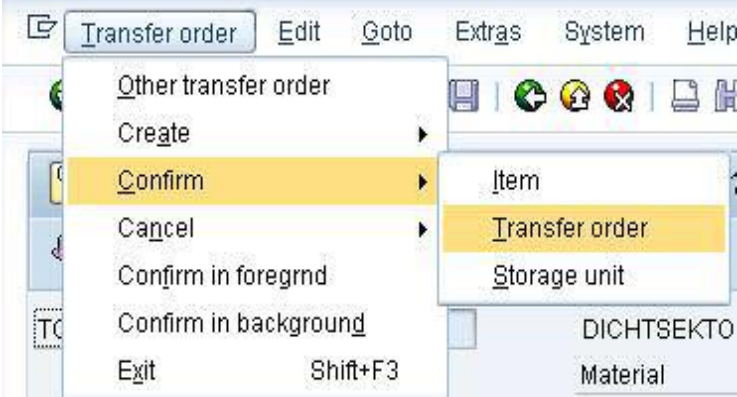

Rys. 15. Potwierdzenie TO - LT21

Źródło: opracowanie własne na podstawie SAP

Wyświetla się okno dialogowe TO, z którego należy wybierać dane wcześniej zapisane w systemie. 


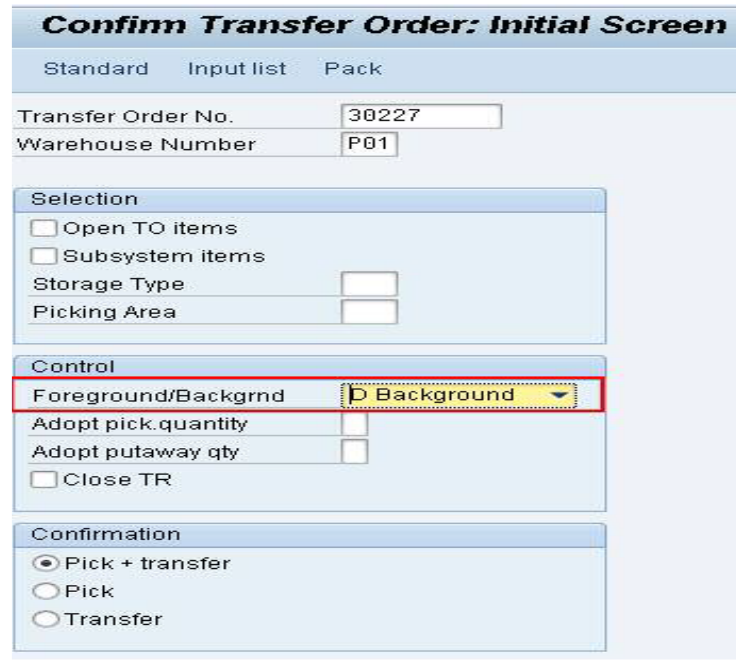

Rys. 16. Zatwierdzenie wyboru - LT21

Żródło: opracowanie własne na podstawie SAP

Klikając w opcje zaznaczoną na powyższym zdjęciu, system pokazuje wcześniej zapisane in-formacje dotyczące przesunięcia materiału (jeszcze nie potwierdzone):

- numer i nazwa materiału,

- zakład / magazyn.

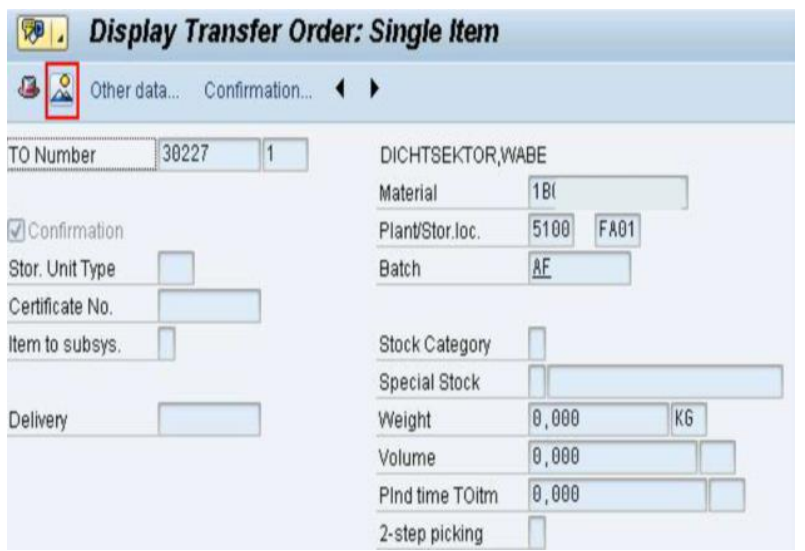

Rys. 17. Widok TO dla pojedynczego materiału- LT21

Żródło: opracowanie własne na podstawie SAP

Po sprawdzeniu danych zatwierdza się przesunięcie. System generuje komunikat potwierdzający przesunięcie interesującego nas TO.

\section{Transfer order 0000030227 confirmed}

Rys. 18. Potwierdzenie przesunięcia - $\mathrm{nr}$ TO

Żródło: opracowanie własne na podstawie SAP

Wyświetlając szczegóły potwierdzonego TO system informuje o przesunięciu materiału z lokalizacji PP1 do magazynu docelowego N01 wraz z datą zdarzenia.

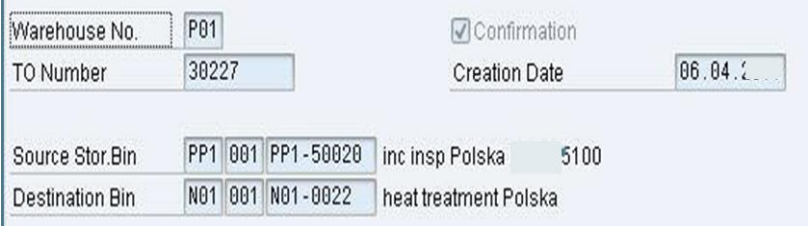

Rys. 19. Szczegóły przesunięcia - LT21

Żródło: opracowanie własne na podstawie SAP
Otrzymujemy następujące informacje z systemu:

- numer TO,

- data utworzenia TO,

- osoba tworząca TO oznaczona numerem identyfikacyjnym YKP0160,

- data potwierdzenia TO,

- rodzaj ruchu magazynowego 999 - przesunięcie,

- opcje i status wydruku.

\begin{tabular}{|c|c|c|c|c|}
\hline Narehouse Number & P01 & Creation Date & $06.04: 2$ & $13: 26: 37$ \\
\hline Iransfer Order No. & 30227 & User & YKP0160 & I \\
\hline \multicolumn{5}{|c|}{ Confrmation, planned and actual data } \\
\hline D) confirmation & & Plan Time WM & 0,000 & \\
\hline Confirmation Date & 21.02 .21 & Plan time ext.syst. & 0,000 & \\
\hline Personnel No. & $\theta$ & Actual Time of TO & $\theta, 000$ & \\
\hline HR status of TO & $\square$ & Start Date & & $\theta \theta: 0 \theta: 00$ \\
\hline PerformanceData & $\square$ & End Date & & $00: 00: 00$ \\
\hline$\square$ input ramnt for act data & & Act time req in To & $\square$ & \\
\hline Deviation pinfactual & $\theta$ & TO proc comment & $\square$ & \\
\hline \multicolumn{5}{|l|}{ Reference data } \\
\hline TR Number & 9 & Sales document & & \\
\hline Posting Change Number & $\theta$ & Material Document & & \\
\hline Group & & Transfer Order Type & $\square$ & \\
\hline Req. Tracking Number & $\Pi[$ & Additional Number & & \\
\hline \multicolumn{5}{|l|}{ Other data } \\
\hline Movement Type & 999 & Print code & 01 (n)TC & Finted \\
\hline Door & & Staging Area & & \\
\hline Gueue & & To priority & $\theta$ & \\
\hline
\end{tabular}

Rys. 20. Szczegóły przesuniętego materiału - LT21

Żródło: opracowanie własne na podstawie SAP

\section{POBRANIE TOWARU Z MAGAZYNU W MODULE WM}

W przedsiębiorstwie produkcyjnym pobranie towaru z magazynu odbywa się na podstawie wewnętrznych zleceń produkcyjnych. Dział planowania i zaopatrzenia produkcji odpowiedzialny jest za przekazanie informacji o zapotrzebowaniu materiałowym do działu logistyki magazynowej, z którego odbywa się wydawanie materiałów. Zadaniem gospodarki magazynowej natomiast jest optymalne rozdysponowanie materiałów i półfabrykatów do poszczególnych wydziałów produkcyjnych. Operacje i czynności związane z realizacją zlecenia produkcyjnego obejmuja:

- przeformowanie materiałów,

- wybieranie materiałów według zleceń produkcyjnych,

- przemieszczanie materiałów do wydania na produkcję.

Zlecenie produkcyjne generowane $z$ sytemu SAP zostaje przekazane na magazyn w formie papierowej, tzw. przewodnika. Dokument ten zawiera informacje o zapotrzebowaniu na dany materiał. Najważniejsze dane niezbędne do wydania materiału to:

- numer zlecenia produkcyjnego,

- numer materiału,

- nazwa materiału,

- ilość konieczna do realizacji zlecenia,

- data wydania przewodnika,

- osoby odpowiedzialne za wydanie zapotrzebowania,

- numer rysunku.

Po przekazaniu przewodnika, do osób odpowiedzialnych za pobranie materiału $\mathrm{z}$ magazynu, podstawowym zadaniem jest sprawdzenie stanu zapasu. Istnieja przypadki, kiedy ilość zapasu jest nie-wystarczajaca do wymaganego. Ma to miejsce, kiedy np. towar nie został jeszcze przyjęty na stan magazynowy, nastapiło opóźnienie $\mathrm{w}$ dostawie materiału lub materiał został wstrzymany przez kontrolę jakości z powodu wad czy braku odpowiednich dokumentów, certyfikatów.

Sprawdzanie stanu magazynowego materiału pobieranego do zlecenia wykonuje się przy pomocy transakcji MMBE. W oknie dialogowym (rys. 21) wpisuje się numer interesujacego materiału, po czym zatwierdza się wybór. W zakładce „środowisko” dokonuje się wyboru interesujacej opcji. W tym przypadku chcac sprawdzić 
stan zapasu wybiera się opcję „stan magazynowy WM”. Pojawiaja się dane 0 aktualnym stanie materiału oraz miejsce składowania zapasu - magazyn LX6.

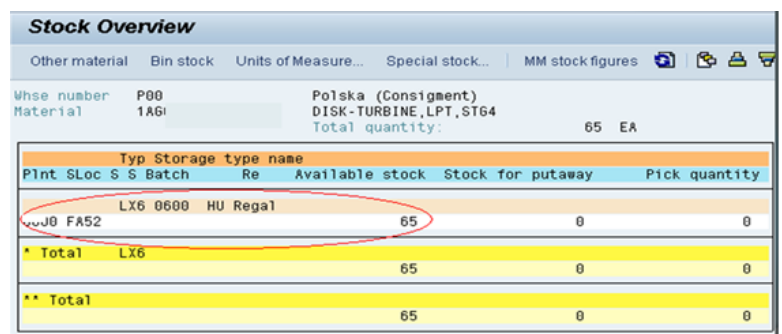

Rys. 21. Transakcja MMBE

Źródło: opracowanie własne na podstawie SAP

Jeżeli ilość wymagana jest wystarczająca do zapasu wówczas przechodzi się do etapu pobierania materiału. Używa się w tym celu z transakcji CO27. W oknie dialogowym wpisuje się numer zlecenia produkcyjnego na podstawie przewodnika. Po poprawnym wprowadzeniu numeru system pokazuje wszystkie dane materiałowe wraz z ilościa potrzebna do zlecenia (informacja ta została zarejestrowana w systemie podczas tworzenia zlecenia). Pobieranie następuje poprzez zatwierdzenie, tak jak na rys. 22

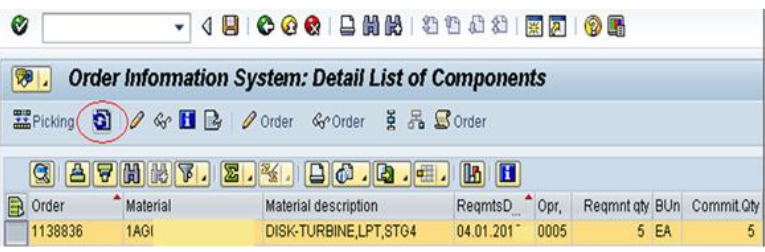

Rys. 22. Transakcja $\mathrm{CO} 27$

Źródło: opracowanie własne na podstawie SAP

Jeżeli system nie wyświetli powyższego okna dialogowego oznacza to, że numer zlecenia został błędnie wprowadzony. System pokaże komunikat o braku zlecenia. W przypadku pozytywnego wyniku i zatwierdzeniu pobrania system przetwarza dane o przemieszczeniu materiału. Stan magazynowy zapasu zmniejsza się o pobraną ilość i następuje systemowe przemieszczenie materiału.

Wykorzystując transakcję ZT22 drukuje się TO ze spikowanego zlecenia. W oknie dialogowym należy wyszukać interesujace TO poprzez ograniczenie wyboru do numeru magazynu, typu magazynu lub numeru gniazda. Po określeniu parametru wyboru pojawia się lista wszystkich TO. Z uwagi na interesujace TO wg zlecenia 1138836 filtruje się listę i wyszukuje tylko istotne TO. Zaznacza się TO (może wystapić więcej niż jedno) i przechodzi się do opcji drukowania. W lewym górnym rogu okna dialogowego wybiera się polecenie drukowania. Po wykonaniu zadania system informuje o zakończeniu drukowania wyświetlając komunikat „drukowanie kompletne".

Ostatnią czynnością kończącą etap wydawania towaru z magazynu jest potwierdzenie wydania do zlecenia produkcyjnego. Wykonanie tej czynności możliwe jest za pomoca metody bezpośredniej. Wybieramy transakcję LT24, wpisując numer magazynu i numer interesującego materiału, a następnie z listy wybieramy materiał jeszcze nie wydany do zlecenia produkcyjnego (oznaczony czerwonym punktem). Konieczne jest jego zaznaczenie i potwierdzenie wydania poprzez kliknięcie w opcje „wózka”.

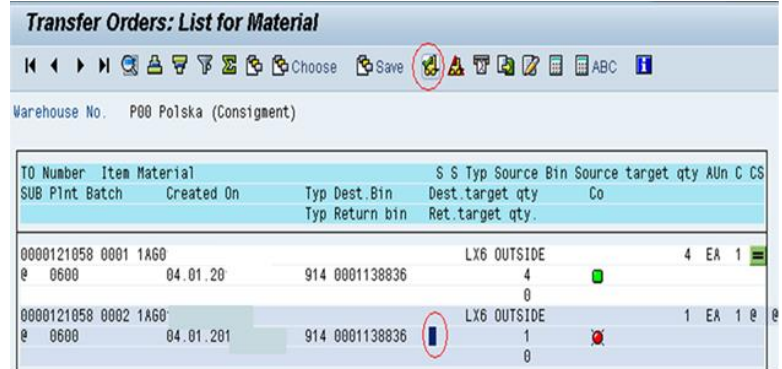

Rys. 23. Transakcja LT24

Źródło: opracowanie własne na podstawie SAP

Wybierając ponownie opcję LT24 możliwe jest sprawdzenie czy materiały zostały przesunięte. Po pojawieniu się listy materiały powinny być oznaczone kropka zielona - oznacza to, że materiały zostały przesunięte do zlecenia produkcyjnego. Wówczas możliwe jest fizyczne pobranie materiału i przekazanie na linię produkcyjna.

\section{WYDANIE Z MAGAZYNU W MODULE WM}

Struktura organizacji gospodarki magazynowej w przedsiębiorstwie rozwiązywana jest według schematów organizacyjnych do których należą te, w których pracę magazynu materiałowego nadzoruje dział zaopatrzenia oraz planowania i kontroli produkcji, natomiast pracę magazynów wyrobów gotowych nadzoruje dział sprzedaży i dział handlowy przy bieżącym współdziałaniu z komórkami logistyki. Zadaniem działów odpowiedzialnych za sprzedaż jest przekazywanie informacji do działu logistyki o planowanej sprzedaży.

Pozyskanie informacji o planowanym wydaniu wyrobów możliwe jest przy pomocy transakcji VL06P. W oknie dialogowym wybiera się numer zakładu, z którego ma nastapić wydanie. W tym przypadku jest to zakład 5111. Po zatwierdzeniu wyboru system wyświetla listę wydań do zrealizowania. Oznacza to, że dział produkcyjny zakończył etap produkcji i wyroby są gotowe do bezpośredniej sprzedaży lub przemieszczenia do strefy składowania, oczekując na wydanie. To dział sprzedaży i dział handlowy podejmuje decyzje jakie wyroby zostaną sprzedane i w jakim czasie. W przypadku przedsiębiorstwa produkcyjnego sprzedaż następuje głównie bezpośrednio z produkcji

\section{PODSUMOWANIE}

W ciagu ostatnich 20-30 lat nastapił dynamiczny rozwój technologii informacyjnej. Aktualnie trudno sobie wyobrazić funkcjonowanie przedsiębiorstw bez komputerów, nowoczesnych urządzeń czy systemów informatycznych. W dobie XXI w. rezygnacja z nowoczesnych rozwiązań, zwłaszcza w obszarze gospodarki magazynowej, może skutkować poważnymi konsekwencjami. Konkurenci wspierając swoją działalność wydajnymi systemami zarządzania oraz wykorzystujac najnowsze osiagnięcia w obszarze controllingu i metod zarządzania wpływają na działalność przedsiębiorstw rezygnujących z tych usprawnień, zmniejszając ich znaczenie na rynku. Innowacyjność i elastyczność dostosowania się do nowoczesnych technologii to podstawowe zasady jakimi każda organizacja powinna kierować się w celu osiagnięcia maksymalnych korzyści.

Jednym z rozwiazań informatycznych stosowanych w biznesie jest właśnie system klasy ERP - SAP. Dla przedsiębiorstw, szczególnie tych funkcjonujących w branży produkcyjnej, system jest podstawowym narzędziem obsługi procesów logistycznych. Ewidencjonuje wszystkie zdarzenia związane z obsługą produkcji. Umożliwia dostęp do informacji w zakresie planów produkcyjnych, zleceń produkcyjnych, etapów procesu produkcyjnego oraz zrealizowanych 
zamówień. Na podstawie planów produkcyjnych wspomaga prace działu zakupów. Minimalizuje stan zapasów przez optymalizację procesów dostaw towarów, zapewniając płynność finansową przedsiębiorstwa.

Dzięki implementacji z modułem WM system daje możliwość śledzenia ruchu partii towaru, poprawia jakość obsługi magazynu , wspiera zarządzanie ich powierzchnią oraz umożliwia ewidencję przesunięć towarów wraz z pełną historią operacji. Tworzenie raportów pozwala na analizę i kontrolę procesów oraz rozliczanie czasochłonności pracy na poszczególnych stanowiskach roboczych.

Wybór systemu pozostaje w gestii przedsiębiorcy. Przedstawiona analiza systemu informatycznego, na podstawie przedsiębiorstwa produkcyjnego, miała na celu zapoznanie z wszystkimi aspektami jego funkcjonowania. Charakterystyka systemu, w obszarze zarządzania magazynem przybliżyła rozwiązania wykorzystywane w procesach magazynowych. Zalety i wady systemu ułatwiaja podjęcie indywidualnej decyzji o wdrożeniu systemu informatycznego. Z pewnością prawidłowo skonfigurowany i wdrożony system SAP jest podstawą do wzrostu wartości średnich i dużych przedsiębiorstw, w dowolnym obszarze działalności. Natomiast moduł WM, wykorzystywany w magazynach o dowolnej wielkości i stopniu skomplikowania procesów, staje się wyspecjalizowanym narzędziem zarządzania gospodarką magazynową przedsiębiorstwa $[1,2,3]$.

\section{BIBLIOGRAFIA}

1. Auksztol J., Balwierz P., Chomuszko M.: „SAP zrozumieć system ERP", Wydawnictwo Naukowe PWN, Warszawa 2013
2. Mazzullo J., Wheat P. „SAP R/3. Podręcznik użytkownika”, Helion, Gliwice 2006

3. Missbach M., Anderson G. "SAP w 24 godziny. Wydanie V”, Helion, Gliwice 2016

4. Niemczyk A., „Zapasy i magazynowanie”, Tom II, Magazynowanie, Podręcznik do kształcenia w zawodzie technik logistyk, Instytut Logistyki i Magazynowania, Poznań 2007

\section{Analysis of warehouse service process using WM SAP R/3 module}

On the example of SAP software in the WM warehouse module, the article discusses analysis of the warehouse service process in a selected production company. A practical description of the warehouse activities will explain the importance of using the WM management system. This allows you to evaluate the storage process

Autor:

mgr inż. Dawid Latała - Politechnika Rzeszowska im. Ignacego Łukasiewicza, Wydział Budowy Maszyn i Lotnictwa, Katedra Technologii Maszyn i Inżynierii Produkcji

JEL: 018 DOI: 10.24136/atest.2018.255

Data zgłoszenia: 2018.05.29 Data akceptacji: 2018.06.15 